\title{
Unmet psychosocial needs in CAPS
}

\author{
G Erbis ${ }^{1}$, T Sergiichuk', S Hansmann ${ }^{1}$, I Haug ${ }^{1}$, SM Benseler ${ }^{2}$, J Kuemmerle-Deschner ${ }^{1 *}$ \\ From 8th International Congress of Familial Mediterranean Fever and Systemic Autoinflammatory Diseases \\ Dresden, Germany. 30 September - 3 October 2015
}

\section{Introduction}

Cryopyrin-associated periodic syndrome (CAPS) is a rare autoinflammatory disease. Generalized manifestations like recurrent fever and fatigue and organ disease like reduced vision, hearing loss, bone deformities and aseptic meningitis impair patients' well-being. While most physical complaints are well defined and managed by effective IL-1 inhibition, areas of psychosocial needs are much less explored and often unsatisfied even in treated patients.

\section{Objective}

To identify unmet needs in the psychosocial support of children and adults with CAPS.

\section{Patients and methods}

A qualitative study of children and adults diagnosed with CAPS cared for at the autoinflammation reference center Tuebingen was performed. Patients and their families were invited to participate in structured focus group interviews grouped according to age and involvement with the disease: children $<14$ years, adolescents and young adults $14-21$ years, adults $>21$ years; parents; other family members). Open questions were asked to the group. The group discussion was recorded, transcribed to text and analysed for mentioning of certain topics. Frequency of naming and relevance indicated by discussion participants was calculated and graded.

\section{Results}

The five focus groups comprised of 42 individuals including 25 CAPS patients; 10 females, 15 males, including five children, eight adolescents/young adults and 12 adults. In addition unaffected individuals included 14 parents and three other family members. Key domains of unmet needs identified included information about the disease, understanding of patients' needs, intervention in social

\footnotetext{
${ }^{1}$ University Hospital Tuebingen, Department of Pediatrics, Division of Pediatric Rheumatology, Tuebingen, Germany

Full list of author information is available at the end of the article
}

network and exchange of experiences. The area of need identified in all focus groups and named most often was school. Specifically lack of appreciation by teachers (13) and fellow students (21) was named. In adolescent and adults groups other frequently named areas were employment agency, health insurance organizations and general practitioners.

\section{Conclusion}

Major unmet needs of children and adults with CAPS were identified as various displays of ignorance by the patients' environment. The need for psychosocial support exists particularly in school.

\section{Authors' details \\ ${ }^{1}$ University Hospital Tuebingen, Department of Pediatrics, Division of Pediatric Rheumatology, Tuebingen, Germany. ${ }^{2}$ University of Calgary, Rheumatology, Alberta Children's Hospital, Calgary, Canada.}

Published: 28 September 2015

doi:10.1186/1546-0096-13-S1-P175

Cite this article as: Erbis et al: Unmet psychosocial needs in CAPS.

Pediatric Rheumatology 2015 13(Suppl 1):P175.

Submit your next manuscript to BioMed Central and take full advantage of:

- Convenient online submission

- Thorough peer review

- No space constraints or color figure charges

- Immediate publication on acceptance

- Inclusion in PubMed, CAS, Scopus and Google Scholar

- Research which is freely available for redistribution
C Biomed Central

(c) 2015 Erbis et al. This is an Open Access article distributed under the terms of the Creative Commons Attribution License (http:// creativecommons.org/licenses/by/4.0), which permits unrestricted use, distribution, and reproduction in any medium, provided the original work is properly cited. The Creative Commons Public Domain Dedication waiver (http://creativecommons.org/publicdomain/ zero/1.0/) applies to the data made available in this article, unless otherwise stated. 